\title{
GREEN DATA CENTER DESIGN OF UDAYANA UNIVERSITY
}

\author{
Komang Ery Rusdiana ${ }^{1}$, Linawati ${ }^{2}$, I Made Oka Widyantara ${ }^{3}$
}

\begin{abstract}
Data center of Udayana University has not been integrated yet, so that it caused excessive power usage. Thus, a green data center system has to be implemented to make the power usage more efficient and eco-friendly. This study aims to find out the energy consumption of the data center in Udayana University; and to design the data center based on the criteria and standards of the green data center. Data of this study were collected by conducting a direct survey to the data center, interviewing the IT staffs and analysing the data center conditions. Then, green metrics calculations were conducted, including Power Usage Effectiveness (PUE) and Data Center Infrastructure Efficiency (DCIE) in addition to designing the green data center. This study reveals that the energy consumption in the data center is $\mathbf{1 0 4 . 2 3 1} \mathrm{w}$. in which the PUE calculation is 2,51 included as an inefficient categorization and the DCIE calculation is $39 \%$ that means the power usage efficiency is $39 \%$. Relying on the results, servers grouping is redesigned to minimize the cable usage and to make the checking activities easier, using a raised floor based on designed cooling systems, using 3 phase electrical systems to balance the load distributed, and redesigning the cooling system by using a row oriented cooling system and the cabling system in the data center. By designing the green data center in Udayana University, it is expected that the energy consumption could be significantly reduced and the efficiency could be increased.
\end{abstract}

Keyword-green data center, green metrics, Power Usage Effectiveness, Data Center Infrastructure Efficiency, row oriented cooling system

\section{INTRODUCTION}

The data center is the central storage, physical or virtual media storage, management, and deletion of data and information from the certain knowledge. The data center is a collection of server or computer room. [1]

The data center at the University of Udayana use a lot of power, used to run the main device and to cool the equipment. Therefore, need data center management to be more efficient and more environmentally friendly energy called green data center.

Green data center similar to the data center which are used for media storage, management, and distribution data. The difference is the hardware, the electricity, and computer systems. All designed to achieve maximum efficiency and

${ }^{1}$ Mahasiswa, Jurusan Teknik Elektro dan Komputer Fakultas Teknik Universitas Udayana, Jln. Jalan Kampus Bukit Jimbaran 80361 INDONESIA (telp: 0361-703315; fax: 0361-4321; e-mail: rioadiprasetya@gmail.com

${ }_{2,3}$ Dosen, Jurusan Teknik Elektro dan Komputer Fakultas Teknik Universitas Udayana, Jln. Jalan Kampus Bukit Jimbaran 80361 INDONESIA (telp: 0361-703315; fax: 0361-4321; e-mail: 2 widyadi@unud.ac.id, ${ }^{3}$ igakdiafari@unud.ac.id minimal environmental impact [1]. Green data center means sustainable data center efficiently in the process, energy, and equipment used [2].

Research was conducted on data center located in GDLN (Global Development Learning Network) Udayana University. This data center serve data access across the campus of the University of Udayana at Sudirman, Jalan Pulau Nias and Jimbaran.

Data center at Udayana University is not well integrated and caused the cost is high enough to maintenance.

\section{DATA CENTER}

Data center is a facility used to place a computer system and its related components, such as telecommunications and data storage systems. This facility typically consists of redundant power or a backup, redundant data communication connections, environmental control, fire prevention, as well as physical security devices. The data center also covers a server storage for a website or database.

The data center is managed by the administrator. Good management of data center supports the entire performance of the network, which both support the entire performance of the network, from the use of the application, therefore the rules and standards of measurement is critical of the use of applications, from data center administration [3].

\section{A. Data Center Component}

Based on "Classification of Data Center Infrastructure Management (DCIM) Tools" paper [4], the data center has a term used to describe and differentiate center infrastructure, data management and classification system as shown in table 1

\section{B. Criteria for Designing Data Center}

In the planning of the data center, should consider the following criteria:

1. Availability. The data center was created to be able to provide sustainable operations and continuous for a company either in normal circumstances and in case of the occurrence of a significant damage or not. Data centers should be made as far as possible closer to zero failure for all of its components.

2. Scalability and Flexibility. The data center should be able to adapt to the needs of rapid growth or when the new services to be provided by the data center without making a significant change to the data center as a whole.

3. Security. The data centers storing valuable corporate asset, therefore the security system is made as tightly as possible both securing physical and non-physical security [5]. 


\section{Data Center Standard.}

In this study used TIA-942 standard to designing a data center. Telecommunications Industry Association's TIA-942 is a standard that specifies minimum requirements for telecommunications infrastructure of data centers and computer rooms. Topology proposed in this standard are intended to be applied in any size data center. This standard was first published in 2005, after the cable structured work defined in TIA / EIA-568, and is often cited by companies such as ADC Telecommunications and Cisco Systems. In April 2005, responding to the TIA standards TIA-942 infrastructure, data center first standard to specifically address the data center infrastructure. Intended for use by data center designers in the building process, TIA-942 includes the space and layout, cabling infrastructure, tiered reliability, and environmental aspects. [6].

Table 1: Terminology Definition And Examples Data Center [4]

\begin{tabular}{|c|c|c|}
\hline Term & Definition & $\begin{array}{c}\text { Data Center } \\
\text { Examples }\end{array}$ \\
\hline $\begin{array}{l}\text { Facility and } \\
\text { IT } \\
\text { Infrastructure }\end{array}$ & $\begin{array}{l}\text { This represents the totality of the } \\
\text { material systems and } \\
\text { foundational physical equipment } \\
\text { necessary to facilitate operations } \\
\text { of a reliable, controlled and } \\
\text { secured IT environment. }\end{array}$ & $\begin{array}{l}\text {-Power system } \\
\text {-Cooling system } \\
\text {-Security system }\end{array}$ \\
\hline IT & $\begin{array}{l}\text { The entire spectrum of } \\
\text { technologies for information } \\
\text { processing, including software, } \\
\text { hardware, communications } \\
\text { technologies and related } \\
\text { services. }\end{array}$ & $\begin{array}{l}\text {-Server } \\
\text {-Storage system } \\
\text {-Network system }\end{array}$ \\
\hline Environment & $\begin{array}{l}\text { The total physical surroundings } \\
\text { within a building or facility that } \\
\text { house the various pockets of data } \\
\text { center related hardware and } \\
\text { software. }\end{array}$ & $\begin{array}{l}\text {-IT room } \\
\text {-Electrical room } \\
\text {-Mechanical room }\end{array}$ \\
\hline Subset & $\begin{array}{l}\text { Subset A logical grouping of } \\
\text { physical subsystems with similar } \\
\text { primary functions (four of } \\
\text { these). }\end{array}$ & $\begin{array}{ll}\text {-Monitoring } & \& \\
\text { Automation } & \\
\text {-Planing } & \& \\
\text { Implementation } & \\
\text {-Data Collection } & \end{array}$ \\
\hline Subsystem & $\begin{array}{l}\text { A purpose-built software } \\
\text { package that addresses a specific } \\
\text { need (potentially hundreds of } \\
\text { these). }\end{array}$ & $\begin{array}{l}\text {-Facility power } \\
\text { device monitoring } \\
\text {-IT room security }\end{array}$ \\
\hline $\begin{array}{l}\text { Primary } \\
\text { Function }\end{array}$ & $\begin{array}{l}\text { A software function that is first } \\
\text { in order of development and first } \\
\text { in rank or importance when } \\
\text { compared to other software } \\
\text { functions available within that } \\
\text { particular subsystem. }\end{array}$ & $\begin{array}{lr}\text { - The PowerLogic } \\
\text { ION } & \text { Enterprise } \\
\text { software } & \text { Package's } \\
\text { electrical room } \\
\text { power analytics } \\
\text { function } \\
\text { function }\end{array}$ \\
\hline $\begin{array}{l}\text { Secondary } \\
\text { Function }\end{array}$ & $\begin{array}{l}\text { A software function that is } \\
\text { second in rank of importance or } \\
\text { later in order of development } \\
\text { coming after the primary } \\
\text { function. }\end{array}$ & $\begin{array}{lr}\text { - The } & \text { PowerLogic } \\
\text { ION } & \text { Enterprise } \\
\text { software } & \text { package's } \\
\text { facility r HVAC } \\
\text { cooling r device } \\
\text { monitoring }\end{array}$ \\
\hline
\end{tabular}

\section{Data Center Cooling System}

According to Neil Rasmussen [7], which need to be considered in designing the cooling system is a clear path from the source to the cooling server / device in the data center. There are 3 types of air distribution flow occurs, ie flooded, locally ducted, and fully ducted. Can be seen in Figure 1.

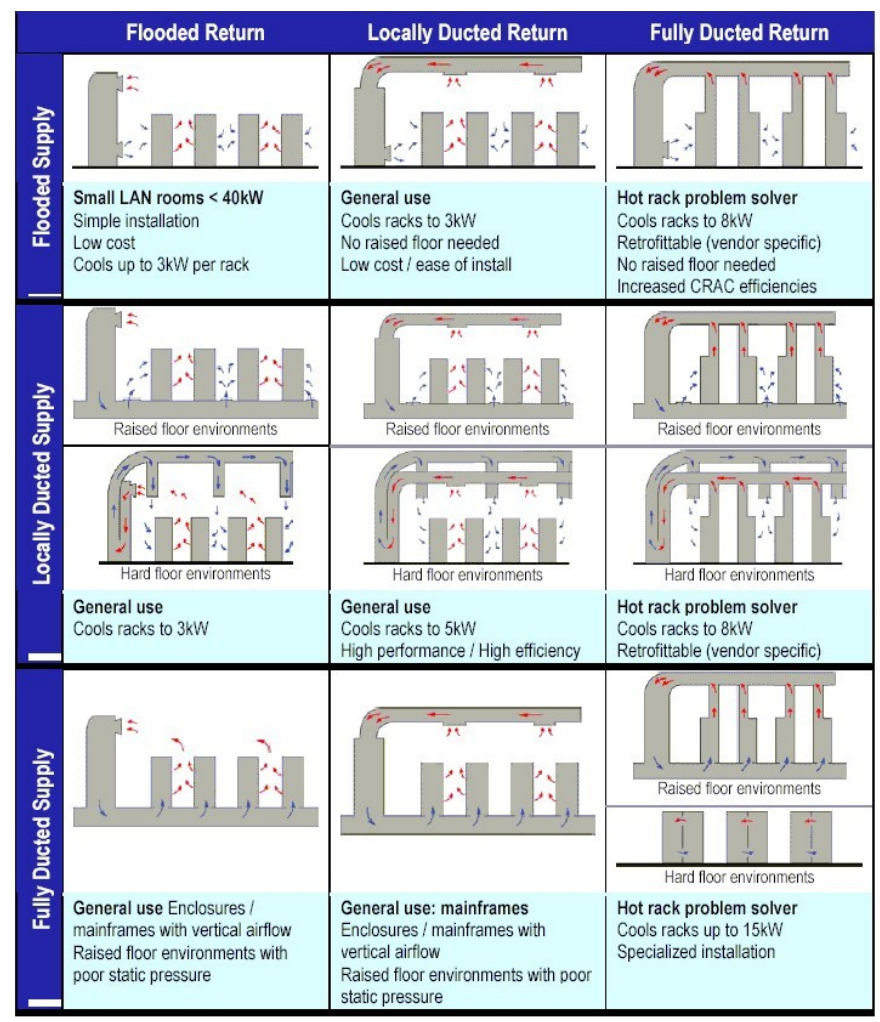

Figure 1: Flow Cooling On Data Center [7].

Determining the needs of the cooling system needed for a data center is required input of the amount of heat generated by IT devices and other heat sources in the data center. measurement requirements using the standard wattage.

\section{E. Green Data Center}

Green data center is a repository for the storage, management, and dissemination of data in which the mechanical, lighting, electrical and computer systems are designed for maximum energy efficiency and produce minimal environmental impacts [2].

Green data center similar to the data center which are used for media storage, management, and distribution data. The difference is the hardware, the electricity, and computer systems. All designed to achieve maximum efficiency and minimal environmental impact [8].

\section{F. Green Metrics}

Green metrics are metrics that evaluate the energy efficiency of a mobile communication system. Green metrics can be divided into two types of metrics level of equipment, and facility-level metrics [8]. In this study, green metrics used are Power Usage Efectiveness (PUE) and Data Center Infrastructure Efficiency (DCiE) offered by the Green Grid.

PUE is the total power used for all equipment in the data center divided by the power used for its IT devices.

$$
P U E=\frac{\text { Total Facility Power }}{\text { IT Equipment Power }}
$$


DCIE can be defined as the ratio of IT equipment power and total facility power.

$$
\text { DCIE }=\frac{\text { IT Equipment Power }}{\text { Total Facility Power }} \times 100 \%
$$

\section{RESEARCH METHOD}

In this study, the first thing to do is analysing the condition of the data center by conducting a direct survey to the data center and interviewing the IT staffs. A journal study method is also used as the basis of proposals in this study. Data and theories are the reference as well as other related research taken from books, journals and papers. The method used is to make modelling design of green data center in order to make the data center efficient in terms of the electricity consumption of the cooling system and the hardware.

Then, the green metrics are calculated. This method is used to determine the level of the green data center design. There are two metrics used that are the Power Usage Effectiveness (PUE) and Data Center Infrastructure Efficiency (DCIE).

In this study, the development of the current green data has no signs that expressly or clearly. So that all the components that support the development of the green data center is concluded into the Green Data Center Best Practices.

\section{RESUlt AND ANALYSIS}

\section{A. Existing Condition of Data Center Cooling Systems}

A room-oriented cooling system is a method used in the data center of Udayana University. There are three standing $\mathrm{AC}$ and $3 \mathrm{AC}$ that are placed on the wall. The coolers are deployed on the edge of the data center room as seen in the figure 2 below.

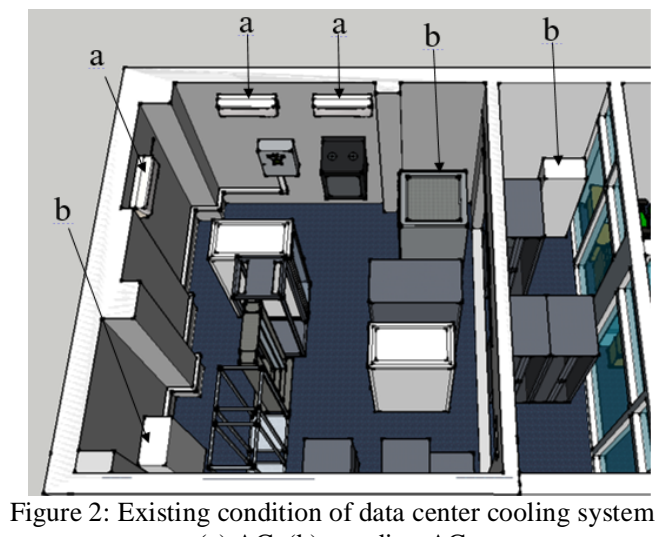

(a) AC, (b) standing $\mathrm{AC}$

Using room-oriented cooling system causes uneven coolers of the device server. The flow of the cold air becomes mixed up and causes excessive energy usage through a cooling device.

\section{B. Evaluation of Power Consumption}

Power usage in the data center of Udayana University comes from electricity generation and also with a backup generator. From the power source, it is connected to the 4

Komang Ery Rusdiana: green data center design...........
MCB. From $4 \mathrm{MCB}$, it is connected to one UPS with $40 \mathrm{kVA}$ power. UPS will be directly connected to the data center that is in the 2nd floor of the GDLN building.

To be able to calculate the amount of power consumption required for existing IT device, the calculation could be done based on the specifications of the existing device.

The total power used in the data center amounted to $104,231 \mathrm{w}$ while the total power for its IT equipment for $41,391 \mathrm{w}$.

\section{Green Metric Calculation}

1. Power Usage Effectiveness (PUE)

PUE calculation is obtained by dividing the total amount of power used by the data center's total power of its IT equipment (2).

$$
P U E=\frac{104,231}{41,391}=2.51
$$

From the results, the value is obtained based on the criteria of 2.51 PUE value. This value includes the category of inefficient where the total power usage of data centers for greater use refrigeration equipment and supporting components of power consumption for IT equipment.

\section{Data Center Insfrastructure Efficiency (DCIE)}

DCIE calculation is obtained by dividing total amount of power used IT equipment to the total power used (2).

$$
\text { DCIE }=\frac{41,391}{104,104} \times 100 \%=39 \%
$$

Based on the criteria of DCIE value, the result of this calculation is an inefficient category in which the efficiency of data center power usage at the University of Udayana is only $39 \%$.

\section{Data Center Design Recommendation}

From the analysis of the existing conditions, the researcher gets an idea to design Udayana University data center in order to minimize the electric power consumption in order to save costs and support green data center movement. The design can be done starting from the data center room, server clustering, raised floor design, installation of electrical systems design, re-design the cooling system and cabling system based on TIA-942 Data Center Standard.

\section{E. Data Center Room of Udayana University}

Determining the location for the data center is important because that location must can be developed. Consideration of the location is the most important requirement that must be met to anticipate IT needs are always increasing, especially the addition of hardware.

In the data center of Udayana University, the room used is $5.45 \times 12 \mathrm{~m}$. The room size $5.45 \times 12 \mathrm{~m}$ assumed to be sufficient for the development of data center Udayana University for 15 years. 


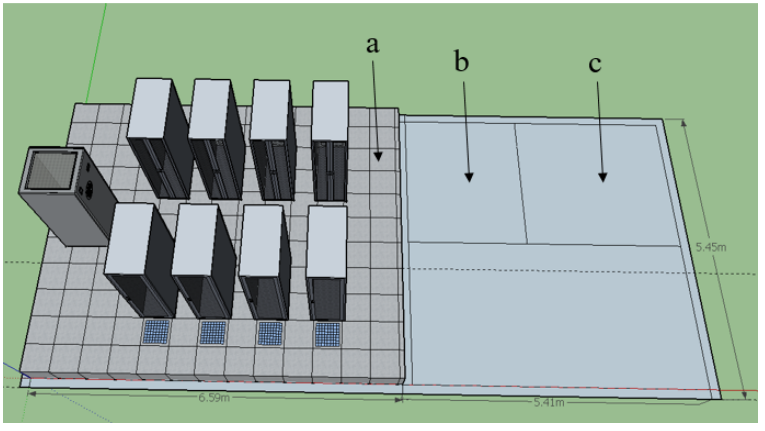

Figure 3: Floor Plan of the data center of Udayana University (a) Server room, (b) control room, (c) official room

In figure 3 the room is divided into four parts of the room. The division of space based on the function of each room.

\section{F. Server Clustering}

Servers clustering is employed according to the functions, types and applications of each device. This server clustering serves to minimize the use of cables and also to facilitate checking when interference with the server.

\section{G. Raised Floor Design}

Data center construction begins with the installation of raised floor. In the design of raised floor made attention to several factors. The first is the height of the floor. There are several factors that affect the height of the floor is ideal for raised floor, including the size and shape of the server environment, the amount of equipment at its maximum capacity, how much cold air that want to pass up, and how much of the infrastructure that will be passed under the floor.

The second factor is the ability to withstand the load floor. More weight can be tolerated by the data center floor. Figure 4 illustrates the design of raised floor using concrete materials or concrete slab, pedestal thermal material and glue on the base of the foundation. The distance from the ground to the tiles is $50 \mathrm{~cm}$. The distance determination takes into account the number of cables and air flow through the raised floor.

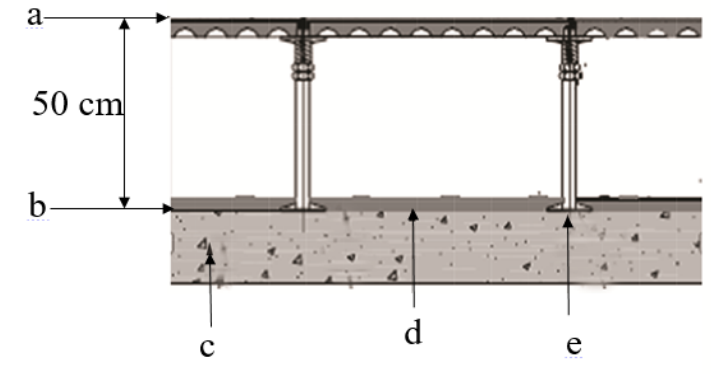

Figure 4: Raised floor design

(a) top of floor, (b) top of concrete, (c) concrete, (d) thermal material, (e) pedestrial glue

\section{H. Installation of Electrical System Design}

Electricity in the data center is supplied by PLN. Because of the amount of the electric power required, it takes 3 phase electrical installations.

3 phase electrical installation is divided proportionally between the server rack and cooling. Line phase $\mathrm{R}$ is used for cooling equipment, line phase sequence $\mathrm{S}$ is used for upper rack and line phase $\mathrm{T}$ is used to lower the rack rows each of 50A. As shown in Figure 5.

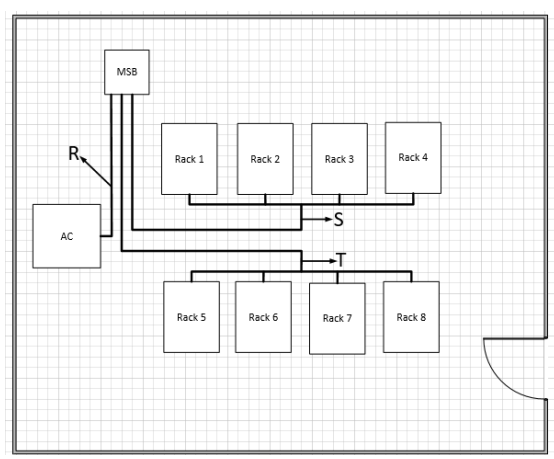

Figure 5: Installation of electrical 3 phase

In the design of electrical systems (power) will be used trench (Tray inside the raised floor) as well as the tray is located just below the main roof. NYY type of cable used as sufficient to conduct electricity to each device, and also more secure because there is a system that can strengthen holder hook wires on the connector. Each rack is connected to the electrical system, given ceeform connector to flow of electric current.

\section{Redesign Cooling System}

From several existing cooling systems, the cooling conditions that exist in the data center of Udayana University is the room-oriented cooling system, the author makes the design of the cooling method that is row-oriented cooling system. Row oriented cooling system design at Udayana University can be seen in Figure 6.

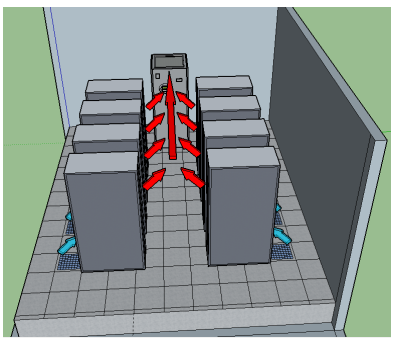

(a)

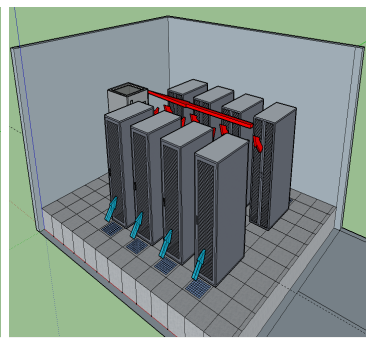

(b)
Figure 6: Row oriented cooling system (a) top view, (b) side view

Hot aisle is indicated by red arrows, while the cold aisle is indicated by the blue arrows. CRAC position is on hot aisle path to be the rising hot air can be inhaled by CRAC without mixing with cold air.

Cold air flowed through the cold aisle, created under the floor to the front of the server rack. Then the cold air is inhaled by the server to reduce the heat in the server and air heat discharged to the rear rack server. After the hot air will rise up and be inhaled by CRAC.

This method is more efficient because the cold air that is inhaled by the server are not mixed by hot air.

With row oriented cooling system, level of power consumption on cooling in the data center of Udayana University can dropped significantly. 


\section{J. Server Rack Placement}

Placement of the device in the data center will affect the air flow that occurs in the data center, and its design will be associated with the layout of the room is set, the composition of cabinet, and cooling devices that will be used. Setting the room layout and placement of various devices in the data center can optimize the function of the cooling system in the data center and even to the type of flooring used or the type of cabinet that will be deployed. Design the placement of the device can be seen in Figure 7.

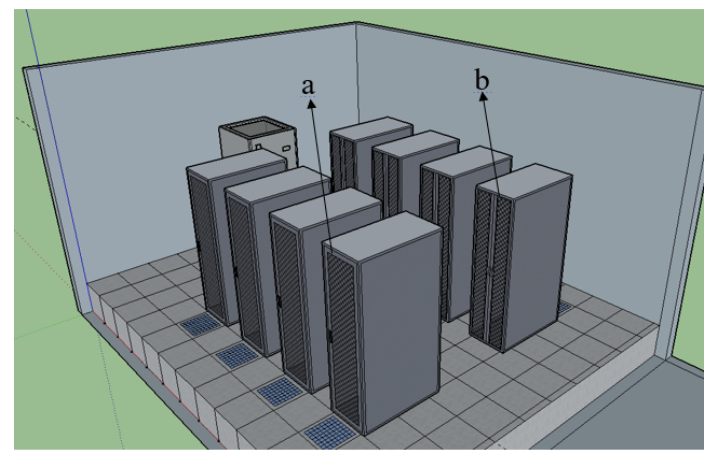

Figure 7: Server rack placement

(a) front side of server rack (b) rear side of server rack

Rows of server racks placed in sequence with the direction the rear of the server racks are facing each other.

\section{K. Cabling System Design Of Udayana University Data Center}

Figure 8 is the design of the existing cabling in data center of Udayana University.

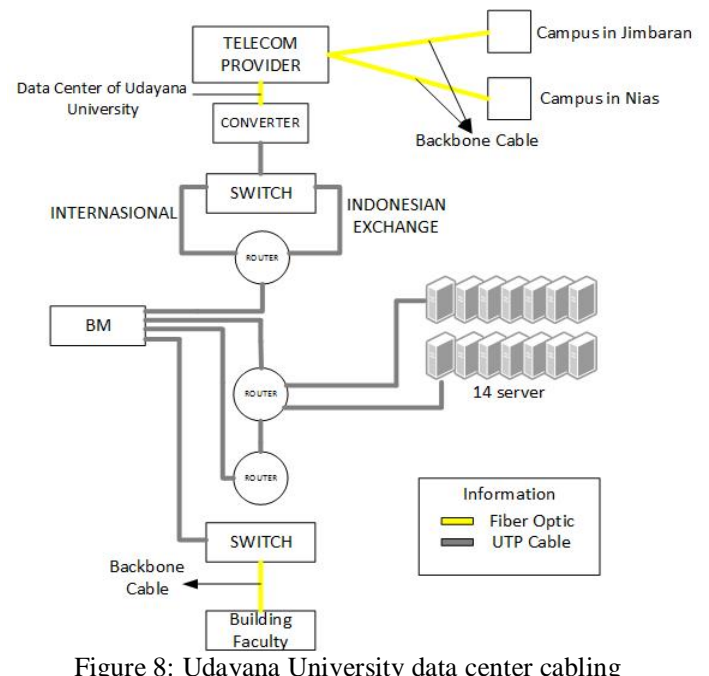

Main switch (metro) from the Telecom provider is the first point of the network infrastructure. This point is connected by fiber optic from Telkom, divided into three heads which are Udayana campus in Bukit Jimbaran, Udayana University campus in Nias and Udayana University in PB Sudirman street. Fiber optic from Telkom connected to a switch using a converter Small Form-factor Pluggable (SFP). On the switch will be divided into two lanes for International Exchange and Indonesian Exchange. Then go to the BGP router to choose

Komang Ery Rusdiana: green data center design........... the routing International Exchange or Indonesian Internet Exchange (IIX). Of a BGP router is connected (bridging) with a bandwidth manager for the distribution of bandwidth to each ip transit owned by Udayana. Bandwidth manager is connected to the router. At this router is connected to the 14 pieces of the server that functions as the application service provider. Then from the router connected to the nut to be connected to a bandwidth manager is then connected to the switch 4700 . From 4700 switches, each output to the faculty building on the campus of Udayana Sudirman.

Here the researcher has designed a new cabling system for the data center. Figure 9 is the design of data center cabling system at Udayana University.

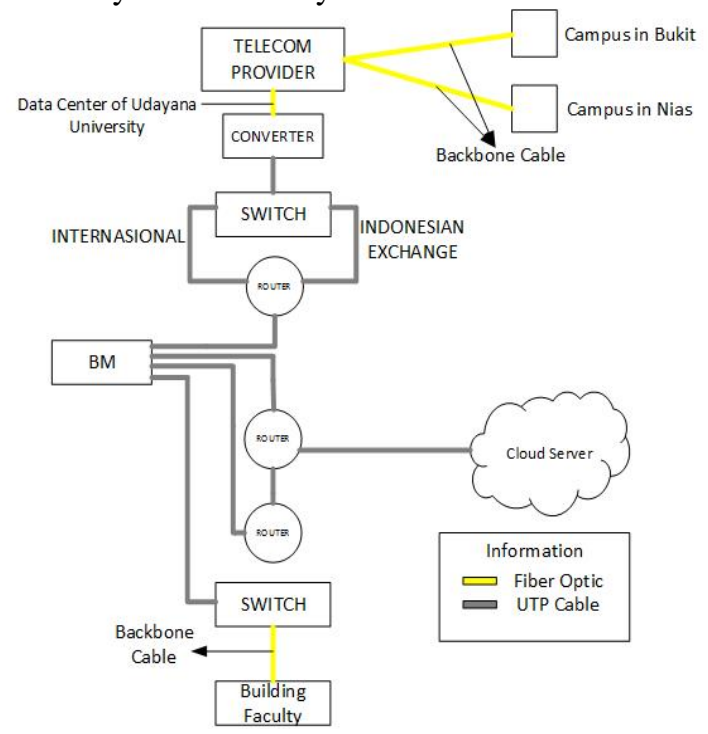

Figure 9: New cabling system design of Udayana University data center

There was little difference in the new design. Where 14 servers causing consume a lot of power and infrastructure is needed. Therefore the new cabling is designed to use 4 server cloud to conserve power and infrastructure equipment used. By using cloud servers, data security can be maintained.

\section{Evaluation of Power Consumption After Design}

After designing a green data center at Udayana University, showed that the total power used $58.995 \mathrm{w}$ while its power to IT equipment that is $27.565 \mathrm{w}$.

The reduction of the number of devices such as ups, ac, servers, switches, routers and storage. Reduction in the number of ac become one due to the design of the new cooling system that is row-oriented cooling system. This system allows the device is standing ac to distribute cool air into two rows of server racks. On the server device to deliberately reduce the number of devices using the cloud system server. This system maximizes the performance of the device server so that multiple servers can be combined into a single cloud server. It will affect the use of power, cabling, and more efficient. From results obtained, it can be calculated Green Metrics PUE (1) and DCIE (2).

$$
P U E=\frac{58,995}{27,565}=2.1
$$

p-ISSN:1693-2951; e-ISSN: 2503-2372 


$$
D C I E=\frac{27,565}{58,995} X 100 \%=46 \%
$$

In comparison with before the design, then the comparison can be seen in table 2

TABLE 2: Comparison Results Before and After Design

\begin{tabular}{|c|c|c|c|}
\hline & $\begin{array}{c}\text { Before } \\
\text { Design }\end{array}$ & After Design & Difference \\
\hline $\begin{array}{c}\text { Power } \\
\text { Consumption } \\
\text { Total }\end{array}$ & $104,231 \mathrm{w}$ & $58,995 \mathrm{w}$ & $45,236 \mathrm{w}$ \\
\hline PUE & 2.51 & 2.1 & 0.41 \\
\hline DCIE & $39 \%$ & $46 \%$ & $17 \%$ \\
\hline
\end{tabular}

From the results, we can see the difference in power consumption in the data center before and after the design is equal to 45,236 w. The results of the calculation of PUE after the design is 2.1. These results is average category with a difference is 0.41 with the calculation before designing. For the calculation of DCIE obtained increased efficiency by $17 \%$ where the efficient use of power after the design reaches $46 \%$.

\section{CONCLUSION}

From the description discussed the design of Green Data Center University of Udayana, it can be concluded:

1. Total power usage in the data center Udayana University facilities and IT equipment power reached 104,231 watts, where the calculation of PUE get the result by 2.51 which is inefficient category and DCIE calculation is $39 \%$ which the efficiency of power usage in the data center Udayana University reached $39 \%$

2. The room size used is $5.45 \times 12 \mathrm{~m}$, which for the server room measuring $6.59 \mathrm{~m} \times 5.45 \mathrm{~m}$ is assumed to be sufficient for the development of data center Udayana University for the next 15 years.

3. Clustering the server is to minimize the use of cables and also to facilitate checking when interference with the server.

4. The server room floors are made of raised floor for cable lines and also cold air path from the ac according to a cooling system that is designed, row-oriented cooling system.

5. The design of the cooling system used is row-oriented cooling system that can minimize power consumption. This system of cold air flowing through the cold aisle under the floor to the rear rack server then dumped hot air backward server rack and the hot air will rise up and be inhaled by CRAC.

6. Designed cabling designs use 4 server cloud to minimize power consumption and infrastructure equipment used.

7. The difference of power consumption in the data center before and after the design is equal to $45,236 \mathrm{w}$.

8. The difference of PUE calculation before and after the design is 0.41 and the calculation results for DCIE get the difference of $17 \%$ where the efficient use of power after the design reaches $46 \%$.

\section{REFERENCES}

[1] R. M. Toledo, and P. Gupta, "Green Data Center: How Green Can We Perform?," Journal of Technology Research (tidak ada vol, no, hal, dan tahun)

[2] R. Bauer. (2008) Building The Green Data Center Towards Best Practices and Technical Considerations. [Online]. Available: http://www.snia.org/sites/default/education/tutorials/2009/spring/green/ RickBauer_Building_the_Green_Data_Center.pdf.

[3] Dewannanta, Didha. (2007. Perancangan Jariingan Komputer - Data Center. [Online]. Available: http://www.ilmukomputer.com

[4] Brown, Kevin., Bouley, Dennis. (2012) Classification of Data Center Infrastructure Management (DCIM) Tools. [Online]. Available: http://www.apcmedia.com/salestools/DBOY-7YMKGL/DBOY7YMKGL_R3_EN.pdf? sdirect=true.

[5] Yulianti, Diah Eka., Nanda, Hafda Bayu.. "Best Practice Perancangan Fasilitas Data Center" OpenConten Licence. 2008

[6] TIA. "TIA-942 Data Centre Standards Overview". ADC Krone. 2008

[7] Neil, Rasmusen, "Air Distribution Architecture Options For Mission Critical Facilities," $A P C, 55$ Vol.1 Rev 2, 2011 (tidak ada no, bulan dan nama jurnal tidak jelas)

[8] Milojkovic, A. Chiu, Tommy. (2010) Green Data Center Design - A Holistic Approach. [Online]. Available: http://www.bicsi.org/pdf/presentations/canada2010/Green\%20Data\%2 0Centre\%20Design.pdf.

[9] Wang, Xiaofei, dkk. (2011) A Survey of Green Mobile Networks: Oppurtunity and Challenges. Springer. [Online]. Available: http://mmlab.snu.ac.kr/publications/docs/2011_MONET.pdf. 